\title{
The labyrinthine ways of myth reception: Cretan myths in theme park rides
}

Filippo Carlà, University of Exeter

Florian Freitag, Johannes Gutenberg University Mainz

\begin{abstract}
This article examines the translation of two ancient Greek myths into theme park attractions in European theme parks. Following a very general discussion of the reasons for the popularity of ancient myths in modern media, the authors present a model of cultural translation in theme parks. The model is then applied to two theme park rides in Terra Mítica (Spain) and Parc Astérix (France), both of which, while referring to different myths, rely on the same iconography to establish their theme (the palace of Cnossos). The article specifically addresses scholars interested in classical reception studies and theme park studies, but may be interesting to anyone studying popular culture, cultural translation, adaptation and reception.
\end{abstract}

\section{Keywords}

popular culture

theme parks

Greek myths

classical reception

cultural translation

adaptation 


\section{Introduction}

In his 2013 article 'Dall'hic at nunc all'ubique et semper?'/'From the hic at nunc to the ubique et semper?', Giuseppe Pucci draws on Walter Benjamin and Paul Valéry to argue that the aura of a work of art exists in a strong connection with its entire (mostly spatial) context. A displaced original work of art (e.g. in a museum), Pucci writes, might have a lesser aura for a broad, nonacademic audience than a copy that is located exactly in the spot for which the work was originally conceived - and sometimes the creation of reproductions implies the recreation of the entire context, as in the cases of the caves of Lascaux and Altamira. The starting point of Pucci's reflections, however, is the palace of Cnossos, which is substantially an invention by archaeologist Arthur Evans and his collaborators from the first three decades of the twentieth century, on the spot where the 'original palace' existed. The building integrates the very few fragments from the Minoan times that were found there into a complete architectonic experience (see also Melotti 2008: 9-11). Therefore, Pucci notes,

l'aura che si avverte davanti al trono di Minosse è un'aura indotta artificiosamente, un'aura che si fonda non sull'autenticità del monumento in sé ma sul luogo - sulla location, verrebbe da dire - in cui viene proposta la ricostruzione e sul potere evocativo di essa, sulla capacità che complessivamente ha il sito di fare appello all'enciclopedia dell'osservatore. (2013: 182, original emphasis) ${ }^{1}$

Similarly, Hitchcock and Koudounaris argued that 
the $\operatorname{si}(\mathrm{gh}) \mathrm{t}[\mathrm{e}]$ of Knossos exerts a phenomenological presence that words can not, making it the locus of what Derrida [...] calls 'virtual discourse'. It has recently been pointed out [...] that the object and its context are two sides of the same Kantian coin, perpetually kept in circulation by the institutions of art history, or, in this case, archaeology. (2002: 54)

The palace's specific aura is thus based on its location on the spot of the 'authentic' ruins, as well as on the general power of Crete to evoke Minos, the Minotaur, Ariadne, Daedalus and Icarus - all of the historical and mythical associations, in fact, connected to the island.

Since the 1930s, however, this evocative power of Crete has passed from the location to Evans's invention: although originally a fake, the palace, which substantially revealed to the world the existence of a forgotten civilization, has replaced the island and has itself become a visual 'shorthand' for Bronze Age Greece as well as for Greek mythology. The ancient Greeks, indeed, dated the events related by their mythological tradition to the second half of the second millennium BCE. Eratosthenes, most famously, dated the Trojan War to the years 1189-1179 BCE. The archaeological discoveries of the late nineteenth and early twentieth century, on Crete as well as at Mycenae and Hisarlik, with their palaces dating to those centuries, and the identification of the latter two sites with those mentioned by Homer, led to a direct connection between the Minoic and Mycenean archaeological facies and the mythological material, which could thus find a specific architectonic setting.

The palace's newly acquired evocative power becomes especially obvious when we compare visualizations of Greek mythology before and after the popularization of these archaeological excavations. While later visualizations of Classical myths, such as films, are 
regularly based on these excavations, earlier examples rather feature classical Greek architecture or a pastiche of elements that is intended to evoke an 'ancient' atmosphere. Unfortunately, we do not know how the silent film The Minotaur (Anon., 1910) visualized its mythological setting, since the film has been lost. We do know, however, that La caduta di Troia/The Fall of Troy, a silent film from 1911 directed by Giovanni Pastrone, represents Mycenae as a classical Greek city, while the 'Bronze Age atmosphere' is conveyed through some added Egyptian and Assyrian elements. L'Odissea/The Odyssey (Bertolini, also 1911) makes a more consistent effort to distinguish its representation of Ithaca from the stereotypical forms of classical Greece, but this nevertheless means adopting less elaborate architectures and lively painted columns and walls the geometric decorations and the motives of these paintings are directly derived from geometric pottery painting and show no direct connection to the Mycenaean culture. The final result resembles Roman villas more than Bronze Age Greek buildings. Hence, none of these silent films representing Classical myths show, as later films would, the monuments and architectural styles of Mycenae and Troy, which had been excavated by Schliemann in 1871 and which had already become well known by that time.

Following Evans's creation and its progressive popularization through tourism and the media, not only Troy and Mycenae but also Cnossos found their way into popular culture: after the 1930s the palace's iconic architecture regularly appears in visualizations of various Greek myths, such as the film Clash of the Titans (Davis, 1981) or the graphic novel Age of Bronze (Eric Shanower, 1998-). Here, it activates, in the reader and the viewer, precisely the 'enciclopedia', which, according to Pucci, had originally been restricted to the location of Evans's invention. 
The palace's evocative power has not only been put to use in films, however, but also in a relatively younger 'visual' medium - namely, theme parks. In The Global Theme Park Industry, Salvador Anton Clavé lists 'local mythological culture' as one of the recurring topics in theme parks (2007: 35). Indeed, in European theme parks such as Terra Mítica (Spain), Parc Astérix (France) or Europa-Park (Germany), ancient Greek myths play a significant role. What is striking, however, is that, like modern representations of Greek myths on the silver screen, cultural translations of these myths into the medium of the theme park ride rely heavily on earlytwentieth-century archaeological excavations and specifically on the palace of Cnossos in their visual design: the adaptations of the myth of the Minotaur to the interactive dark ride 'El Laberinto del Minotauro' at the Terra Mítica park in Benidorm (Spain) and the adaptation of the myth of Daedalus and Icarus to the family coaster 'Le Vol d'Icare' at Parc Astérix in Plailly (France) are both set in a reproduction of Evans's palace. In both cases, the park designers have used the palace to communicate the rides' mythological theme and, more generally, that phase of ('imagined') Greek history to park visitors. Here, then, what Pucci has called 'enciclopedia', the 'aura' or evocative power, has passed from the location to Evans's reconstruction to a reproduction of the reconstruction.

More is at work in these translations of ancient Greek myths into the theme park ride, however. In the following, we employ a general model for cultural translation in theme parks to critically analyse the translation and adaptation of the myths of the Minotaur and of Daedalus and Icarus to Terra Mítica's 'El Laberinto del Minotauro' and Parc Astérix’s 'Le Vol d'Icare'. Focusing on the concrete ways in which the ride designers remediated the mythical content - that is, edited and transferred it to its new cultural and medial context - this article contributes not only to a better understanding of both the theory and practice of these kinds of remediations but 
also to framing classical reception as a process of the continuous adaptation, recontextualization and appropriation of individual elements of antique cultures (see Carlà 2015a).

After first considering the particular role played by mythology in the modern popular reception of ancient Greek culture in general, the essay focuses more particularly on theme parks by presenting a model for cultural translation and applying it to the adaption of Classical mythology in the comparatively new media form of the theme park ride. The two case studies of theme park rides inspired by Cretan mythology serve to concretize the model and simultaneously illustrate the range of meanings that translated myths can acquire in the context of different theme parks.

\section{Myths and the reception of ancient Greece}

The reception of ancient Greece in modern media has been overwhelmingly dominated by myths - films set in ancient Greece, for instance, are mostly inspired by mythical plots and only in very few cases refer to historical events. According to Jon Solomon, 'approximately eighty films have been devoted entirely to Greek and Roman myths' (2001: 101; cf. Verreth 2008: 65-66, with much higher numbers, counting 194 adaptations of Greek tragedies), not counting the infinite number of adaptations, quotations and inspirations. There are different ways to account for this 'success' of myths. Solomon argues that it is, above all, 'the surreal stories, powerful heroes, primordial profundity, and pervading feeling of fantasy' (2001: 101-02) of ancient Greek legends that still make them attractive to a contemporary public. Elaborating on Solomon, we identify five major characteristics of ancient myths that make them easily accessible to and productive also in modern culture: 
1. Once deprived of their religious meaning by Christianization, myths have preserved through all periods a strong moral and aesthetic value - as moral exempla, in particular, they remained ubiquitous in visual arts. Such an interpretation of myths led to their perception as transcultural archetypes of human behaviour, a process that reached its peak in psychoanalysis (see e.g. Zajko and O'Gorman 2013). Having been educated according to the traditional western, and particularly German, school system, which heavily relied on Classical culture, first Freud and then Jung adopted Classical myth as a paradigmatic expression of the subconscious and as a transhistorical and transcultural model (on Freud, see Winter 19971998). The success of their theories and the development of psychoanalysis over the course of the twentieth century have thus made concepts such as the Oedipus complex, derived directly from Greek mythology, into references known and used worldwide. Not only Jung, who introduced Electra complex, but also later psychoanalysts simply followed suit and adopted further myths for psychoanalytic models - for example, the Adonis complex (the popular name for muscle dysmorphia), the Telemachus complex (Recalcati) or the Daedalus complex (Fratini). As formulated by Winter, 'psychoanalysis itself, thus, becomes not only a product but also a purveyor of a particular kind of classical education, with an emphasis on one element of the classical curriculum - Greek tragedy, and in particular the dramas of Sophocles' (1997-1998: 140). And Greek tragedy is, in its turn, inspired by and conveys mythical narratives.

2. Ever since classic antiquity, myths have thus constantly been adapted to different temporal and geographical situations: Greek myths are extremely well known across cultures and potentially speak to all people (cf. Preußer 2013: 62). Their characters and plots have, in a continuously self-reinforcing chain in which the success of one reception generates more 
receptions of the same kind, also become increasingly popular outside the western world. A good example is the reception of Classical myth in Japan, as illustrated by the anime production since the 1970s (see Castello and Scilabra 2015). Indeed, the popularity of myths, considered in their 'universal' value as 'archetypes', is particularly evident in countries and cultures that have a less direct contact with classical heritage: to draw again on the example of films, American films favoured mythology in a much stronger way than did, for example, Italian films (cf. Solomon 2001: 102-03).

3. Due to their being set in prehistoric times, which further underlines their role as archetypes, the reception of myths is not as sensitive as that of history. Conflicts, wars and deaths in myths too have to be seen as 'archetypes' rather than references to specific occurrences from history, which makes them appear less 'real' and their reception less delicate. A show from the Spanish park Terra Mítica, Troya, la Conquista, for instance, has no problem in representing Achilles' death - caused by his excessive pride and challenging the gods - as well as the death of other Greek and Trojan warriors. Such deaths are not perceived by the public as 'tragic' and are indeed quite 'aseptic' because of their being detached from daily life and 'historical reality'.

4. Another reason for the frequent and varied reception of ancient myths is their flexibility, the fact that they can be detached from the sociocultural context of their origin without losing significance and the ability to carry a message. If already in Antiquity, as is well known, there were no 'authoritative' versions of the myths, and many variants of the same story existed (allowing the single author the possibility to 'reinvent' the myth with every retelling), the same applies also to the modern reception of myth. Their perception as 'ancient', indeed, did not transform the myths into 'closed' and fixed narratives, but still allows for a continuous 
readaptation, reinterpretation and reshaping of the plots in order to make their narratives more efficient for the specific aims of their representation. Medea's story, for instance, has thus been adapted in many modern versions of her myth, as in Corrado Alvaro's play La lunga notte di Medea/The Long Night of Medea (1949), in Pier Paolo Pasolini’s film Medea (1969) or in Aribert Reimann's opera Medea (2007/2009), as a symbol for issues of migration, intercultural contact, and acceptance - for example, by interpreting her magical powers as not real, but merely ascribed to her by the unaccepting inhabitants of Corinth (see Carlà 2008; Carruesco and Reig 2015). And to quote the show Troya, la Conquista again, the Trojans here win the Trojan War when Hector, Paris and Helen can, especially thanks to the latter's intervention, kill Achilles. While this is functional to the transmission of particular ideals and values (pride and impiety are punished, love, honesty and religiosity triumph), it is clear how far away this mythical translation is from the ancient models and particularly from the Homeric one. $^{2}$

5. Finally, myths, as action-filled narratives that often involve encounters between human beings and monsters as well as divine or holy individuals, and as narratives that frequently introduce magic or supernatural elements, constitute particularly attractive material for adaption by a wide variety of media, from painting and comics to films and video games. The very successful narrative structure in which humans interact with divine figures without being aware of their real nature, for instance, can be traced back to Homer. In this way, an image of Antiquity is reinforced in which a closeness to the supernatural sphere is assumed as a sign of 'primordiality', thus allowing the projection back into Antiquity of values that one wants to present as 'natural' and 'objective' (see Berti and Carlà 2015: 11-14). 
Solomon notes that, with respect to the reception of Greek myths, Homer and the Homeric cycle always lead, in all media, followed by Jason and Medea, Hercules, Theseus and the Minotaur, Oedipus and eventually Perseus (2001: 124-25). The popularity of the Homeric cycle is hardly surprising: the reception of Greek myths, as any other form of reception, tends to privilege wellknown, popular stories, which draw on pre-acquired knowledge among the public - often due to previous receptions - and therefore attain a high level of recognizability. Indeed, the recognition of recognizability is the very moment of reception, which is always structured and animated by the complex cognitive interplay between a particular medial product, its original referent and preceding forms of reception (see Hughes-Warrington 2007: 23-24, in reference to historical movies). The material that has been selected is transformed according to the cultural, social, political and individual contexts of the reception. This also implies transformations according to the medium and the genre of the reception. Cultural and medial transformations may thus be heuristically separated, but of course they are always interconnected, since concepts of media and genres are culturally specific and cultural change is influenced by specific medial and generic expressions (see Carlà 2015b for a very general analysis).

Reception is not exclusively built on the selection of recognizable material, however, but also on the transformation and translation of this material - in the case of myths, necessarily so, since there is no original. The myth, as a narrative, is always 'materialized' in an authorial text that represents one version of it, one particular appropriation. Greek tragedies represent in many cases our 'source' for knowing Greek myths (and our knowledge of the Oedipus myth is unmistakably dominated by Sophocles' elaboration of it in the Oedipus tyrannus) and thus constitute the 'recognizable' referent of reception. Nonetheless, Sophocles' version is not an 'original', since it draws upon previous versions, oral traditions, local variants, as well as on the 
literary invention and adaptation to his own interests by the author himself. Reconnecting to our fourth point above, indeed, it is known that ancient authors (most famously, perhaps, Pindar, see Hubbard 1987 for one specific example) 'invented' mythic versions, which by no means constitute an 'original', since they are always enlargements, additions, adaptations, ways of 'twisting' previous narratives, showing the same characters and continuous points of contact with already known narratives. The latter is indeed a necessary precondition for their being 'believable' and therefore for attaining their function - as moral examples, as foundations of legitimacy and identity, etc. Hence, there is no 'original' referent, and myths can be conceived of what Marsha Kinder has termed 'supersystems', 'network[s] of intertextuality constructed around a figure or a group of figures' (1991: 122; cf. Scott 2004: 63).

Theme parks are particularly interesting for studies of the reception of Classical myth: by combining architecture, music, landscape design, language, film and performing arts with kinetics to create a multimedial and multisensorial immersive environment, they can accommodate and incorporate an almost infinite number of previous forms of reception in any medium.

\section{A model for cultural translation in theme parks ${ }^{3}$}

The themes employed in theme parks range from recreations of past or exotic cultures (as in our first example, Terra Mítica, which reconstructs the ancient Mediterranean world; see Carlà and Freitag 2015a) to representations of fictional worlds, such as those found in literature, comics or films (as in our second example, Parc Astérix, which is based on the famous comics by Goscinny and Uderzo). Theme parks are primarily commercial enterprises appealing to a very broad public

- this constitutes an additional reason for selecting themes that are well known to and easily 
recognizable for a maximum amount of people, and it also explains why within the selected themes they highlight only the most famous and characteristic aspects. This is why theme parks and themed environments, such as the two parks analysed here, do not constitute an exception to the general reception of ancient Greece: here too myths - and particularly well-known myths play a central role.

A central criterion for both the selection of themes in general and the selection of specific aspects of the theme in particular is set by the nature of theme parks as leisure spaces for all age groups: thus, problematic and/or contested issues (such as slavery) are usually omitted from the themed world. Exceptions occur in the cases of so-called 'dark theming' (see Lukas 2007: 27680) - which may include references to historical periods and events - and seasonal celebrations, such as Halloween, as well as in the case of mythic theming: as already discussed, mythic wars and deaths are most probably perceived as pure fiction and therefore also play a role in theme park receptions of myths. Even here, however, there seems to exist certain taboos, such as incest or infanticide, which impact the selection of mythic themes: no attractions based on Oedipus' or Medea's myths are known to us, although both myths are extremely popular and are frequently represented in literature, theatre, paintings, films, comics, etc.

Selection, however, constitutes but one of an entire set of strategies that govern the processes of cultural and medial translation (of myths, history and fictional stories) in the theme park. A second strategy consists of processes of abstraction, whereby stereotypical and characteristic features of the theme are reduced to iconic and evocative signs or symbols. In the two attractions discussed in this article, for instance, the 'prehistorical' setting of the myths is symbolized by the architecture of the show buildings: both represent the palace of Cnossos, which has come to serve as an icon for Greek pre-poliadic culture (see above). 
Third, the strategy of immersion allows visitors, in contrast to fragmentary presentations (as for instance in museums), to affectively experience the theme. Thus the theme becomes 'real' - even though it may have never existed in the first place, as in the case of myths. To be sure, as narratives without originals that only exist in their numerous receptions in different media, mythical narratives always immerse their audience, but the level of immersivity achieved in the theme park is particularly high because all senses are affected at the same time. The direct experience of the theme is realized through a fourth strategy - namely, multimediality: although the theme park is nowadays recognized as a medium on its own, it nevertheless constitutes (like opera) a 'plurimedial' or hybrid medium that relies on various other media conventionally and historically perceived as distinct.

As suggested by Laura Bieger (2007), the politics of visual cultural translation imply a double movement of transfer and transformation of cultural material. In the context of theme parks, the first two strategies presented above (selection and abstraction) can be understood as processes of 'transfer', while immersion and multimediality represent the specific ways in which theme parks transform their source material (Carlà 2015b). Transfer and transformation help to translate source material from various epochs and areas into components of carefully and functionally designed entertainment spaces, where the source material inevitably assumes a new role. The translation of these cultural materials contributes to the creation of powerful images that are naturalized through their sheer materiality and the absence of any argumentative structure. More specifically, the power of these images consists in their lasting impact on the popular image of specific cultures and narratives and in transmitting underlying ideological messages, values and, most importantly, in the case of historical themes and myths, 
anthropological constants. The theme park thus helps to present certain values as independent of cultural and temporal boundaries.

A concrete example is provided, once again, by the show Troya, la Conquista from Terra Mítica. As already noted, the powerful visualization of the victory of the honest, pious and brave Trojans over the treacherous and impious Greeks is a way of transmitting a very clear set of (conservative) moral values by projecting them into a far-away past and therefore constructing them as transhistorical and atemporal and, hence, as 'natural'. Moving to the Roman section of the same park, all this becomes even more evident in the show 'Hispania' (2011-2012). Here the visitors are confronted with a performance in which the Roman occupants of Spain, depicted as arrogant and lazy, try to subdue the brave and virtuous rebels fighting for the freedom and independence of Spain. Even if they manage at first to arrest the rebels, they are afterwards badly defeated by the Iberian women. It is hard to miss the nationalistic message underlying the entire presentation, as the conservative ideology proposed here attributes the highest importance to courage, strength and military virtue. Hence, translation in the theme park is all the more effective since it not only draws on other media and their visual styles and images to attain higher recognizability but also on the underlying ideological messages they contain.

\section{4. 'El Laberinto del Minotauro'}

Our two case studies, both of which constitute a reception of myths from the Cretan cycle, illustrate the overall complexity of mythical reception in theme parks and showcase possible methodological approaches. First, we would like to discuss a Spanish theme park, opened in 2000, that focuses on ancient Mediterranean cultures (see Carlà and Freitag 2015a). As its name, Terra Mítica, already implies, the park considers myths an essential component of Antiquity, to 
the point where they almost become synonymous with it. This becomes particularly obvious in the two sections of the park dedicated to ancient Greece: Las Islas refers mostly to archaic Greece, to the Aegean islands and to traditions (including myths) concerning sea navigation and travel (see Carlà and Freitag 2015a). Grecia rather focuses on the Classical and Hellenistic world, and features a representation of a paradigmatic Greek polis. Nonetheless, the entrance to Grecia refers to the Mycenaean and Minoic eras with a replica of the Gate of Lions and a dark ride housed in a replica of the palace of Cnossos, 'El Laberinto del Minotauro'.

The choice of the palace of Cnossos for the ride is not at all surprising, since the labyrinth is generally identified with the palace itself. Interestingly enough, even before Evans' arrival on the island, underground stone quarries near Gortyna were identified as the mythical labyrinth of Crete (Castleden 1989: 19-20), an identification that has found new supporters in the 2000s (as if it were possible at all to topographically identify a mythical location). ${ }^{4}$ But since apparently the labyrinth was located in Cnossos already in ancient times (the Hellenistic polis of Cnossos represented it on its coins) ${ }^{5}$ and it had even become a sort of tourist attraction (it already had its own aura!) by the third century AD (Philostratus, Life of Apollonius of Tyana 4.34.2), the discovery of the palace, the first big finds there generated, especially after Evans' arrival in 1900, an enthusiasm that radically changed first the academic and then the popular idea of the labyrinth, simply identifying it with the palace itself. Already in 1901, Rouse warned against such hasty identifications, recalling that the palace, as complicated as it might be, is nothing like a maze. Nonetheless, the identification of the palace itself as the labyrinth is still extremely widespread today and has been supported also with reference to a Linear B table from Cnossos referring to a 'lady of the labyrinth' (KN Gg 702: e.g. MacGillivray 2002: 215, claiming that the word indicates 'a communal district reserved for celebrations'). ${ }^{6}$ 
'El Laberinto' constitutes an interactive shooter dark ride, during which riders travel through the labyrinth in order to confront and kill the Minotaur. Visitors are identified with Theseus - or, rather, with Theseus' companions - and are thus transferred from the material remains of the ancient world to the myth. On their way to the Minotaur, however, visitors encounter a collection of other characters from Greek mythology, from Arachne and the Harpies to the Hydra and the Centaurs. These are all depictured as evil, and visitors have to defeat them before the final confrontation with the Minotaur. None of these characters, however, is directly related to Theseus or to the Minotaur in Greek mythology (many of them appear there rather as the enemies of other heroes and in particular of Herakles and Perseus) and some must undergo a sort of reinterpretation. The best example for this is the figure of Arachne, which appears in the attraction simply as a huge spider with red eyes, dangling over the visitors' heads, while the mythical Arachne is a girl who may be guilty of self-importance but is surely not an evil character. Her use in the dark ride alongside such mythical characters as the Harpies or the Hydra thus constitutes a clear case of cultural translation, probably based on modern arachnophobia and its already existing medial representations, such as the film Arachnophobia (Marshall, 1990) and the eponymous video game (1991).

In fact, with the inclusion of the various mythical characters into the labyrinth the attraction creates a new myth that has its own narrative structure or rather reactualizes the original flexibility of the ancient myth. The narrative of the new myth is strongly based on firstperson shooter video games, with visitors using their laser guns to shoot at the mythical figures and collecting points that are displayed on the ride vehicle.

The medial frame that governs the translation of myth in 'El Laberinto' not only includes video games, however, but also other media, particularly films - Arachne's representation, as 
mentioned, immediately recalls, for example, forms and topoi of horror films. Directly connected to the topic are, of course, peplum films such as Clash of the Titans. Perhaps, most importantly, the film's focus on Andromeda, which featured prominently on the film posters, is reflected in the attraction by the fact that visitors experience the Andromeda scene almost right before the final encounter with the Minotaur, in spite of the fact that there is no connection in Classical mythology between the myth of Perseus and Andromeda on the one hand and the 'Cretan cycle' on the other hand. The attraction also relies on the film's visual presentation of Andromeda, who in both media wears white clothes and a golden headdress. The visuals of the attraction's sea monster, by contrast, significantly departs from those in the film, combining features of the deep sea fish and the whale, an allusion to the Biblical story of Jonas as well as Disney's Pinocchio (Luske and Sharpsteen, 1940).

Several segues in between scenes are decorated with tropical plants and animals as well as ruins, thus pointing to the genre of the adventure film, particularly Steven Spielberg's Indiana Jones series (1981-2008). The chronological collocation of the mythical period in a sort of Urphase of human history is rendered through iconographic references to the prehistoric world that is, not only to the Bronze Age, which would fit with the Minoic setting, but also to the Stone Age. This is particularly evident in the scene representing flying pterodactyls, in the animatronic lion of Nemea, which resembles a dinosaur, or in the Centaurs and the bandits, who strongly evoke prehistoric cave men. The latter are indeed represented as creatures with one pair of legs but two chests and heads, wearing fur clothes with a sort of bronze belt and small leather elements (e.g. armbands), holding clubs and maces. They thus recall the stereotypical presentation of the caveman, who is generally clad in animal skins and furs and uses a mace or a club for all purposes - it is enough to think of the B.C. comic strips (Johnny Hart, 1958-), the 
animated sitcom The Flintstones (1960-1966) or even, somewhat earlier, Buster Keaton's Three Ages (1923; on this film see now Wyke 2013).

A clear operation of adaptation and translation also occurs in the final scene, in which visitors encounter the Minotaur in a room full of mirrors, a possible reference to the famous 'mirror scene' in Orson Welles's 1947 film The Lady from Shanghai, which is also set in an amusement park, or to the final duel scene from 007 - The Man with the Golden Gun (Hamilton, 1974). Another source of inspiration for this scene might have been Friedrich Dürrenmatt's Minotaurus: Eine Ballade/Minotaur: A Ballad (1985), the only work that to our knowledge combines the figure of the Minotaur with a labyrinth of mirrors.

\section{5. 'Le Vol d'Icare'}

Our second example is a ride in Parc Astérix in Plailly, France. Parc Astérix is inspired by the eponymous comic and film series (see Melotti 2008: 53-59), although this inspiration is decidedly less obvious in the Greek section, where the ride is located, than, for example, in the Roman or the Egyptian sector. From the (already few) Asterix comic books and films that are set (at least partly) in Greece, such as Astérix aux Jeux Olympiques/Asterix at the Olympic Games (René Goscinny and Albert Uderzo, 1968), none made it into the park, if not in small details, such as a big vase decorated with a representation of the Twelve Labors of Hercules (which appear in the film Les douze travaux d'Astérix/The Twelve Tasks of Asterix (Goscinny and Uderzo, 1976) and in the illustrated book derived from the film, which was published in the same year) or a very general evocation of the drawing style of the comics in the characters animating the attraction 'La Rivière d'Elis'. 
The striking thing about the attraction 'Le Vol d'Icare' is that it is also, like 'El Laberinto', housed in a replica of the palace of Cnossos. This is not surprising: the name of the attraction already establishes the link to the Labyrinth of Crete, and in popular perception the ruins of Cnossos are not only the best-known building of this island from the Bronze Age period, which is often connected with the 'prehistorical' time of myth, but are directly identified with the labyrinth (see above), which, according to ancient mythography, Daedalus had built to host the Minotaur (e.g. Ovid, Metamorphoses, 8.152-182; on Daedalus' myth, see Lane Fox 2008: 197203).

As in the case of 'El Laberinto', where the labyrinth of the myth corresponds to and motivates the layout of the dark ride, myth and technological aspects of the ride are also inextricably linked in the case of 'Le Vol d'Icare'. At the same time the attraction uses different theme park genres to construct a narrative based on the myth and focuses on the efforts by Daedalus and Icarus to escape from the labyrinth. This is a very popular and widely known variant of the myth, which was, however, not very widespread in Antiquity: only one source (Apollodorus, Epitome 1.12) relates that Daedalus and Icarus were captured in the labyrinth, while the most well-known ancient version, as presented in Ovid, places them as prisoners in a tower (Ovid, Metamorphoses 8.183-259). It is with the eighteenth century and its 'encyclopaedic' works that Apollodorus became in many cases the primary source for Classical mythology, and therefore the success of this variant in recent time can be easily explained.

In contrast to 'El Laberinto', the labyrinth theme in 'Le Vol' is restricted to the waiting area, which, however, constitutes a central part of the narration. The story starts with two signs that help visitors understand that they have entered the labyrinth - or its ruins - and that make clear that it is impossible to find an exit in an easy way. The visitor is thus confronted with the 
same problem as Daedalus and Icarus. The ruin character of the building, the absence of any living creatures, and the 'museal' presentation of the traces of Daedalus, which we will describe in a moment, do not invite the visitor to directly identify with Daedalus or Icarus, but rather to imply that he or she, as a modern visitor or archaeologist, is forced to repeat it.

Later in the waiting area visitors encounter glass cases that display some of Daedalus' failed attempts to fly out of the labyrinth, as well as Daedalus' lab. Through these displays Daedalus is constructed, at variance with the traditional mythic image, as a timeless 'mad scientist' who invents all sorts of impractical devices and who is associated with popular images of premodern flying devices from Greek (Hermes' sandals) and non-Greek iconographies (Leonardo's 'flying machine'). Daedalus' lab (the biggest display) presents the apparent solution to Icarus' and the visitors' problem in the form of different studies about birds. These are recalled in the last section of the waiting area by frescoes representing feathers.

After the waiting area, the visitor reaches the roller coaster itself, whose cars are also adorned by big white feathered wings. The roller coaster's lift hill constitutes the next chapter of the narration. The ride vehicles slowly ascend, and Daedalus' solution appears to work. At the top of the lift hill, however, a huge sun sculpture is positioned right before the first drop of the coaster, with a clear direct reference to Icarus' fall due to his proximity to the sun. Following the drop, visitors experience a very turbulent flight, sometimes only narrowly avoiding the palace, sometimes apparently regaining stability, but eventually finding themselves back at the starting point - in the labyrinth.

Hence, 'Le Vol d'Icare' does not feature an amalgamation of different myths like 'El Laberinto', but rather a translation of the Greek myth into the family coaster genre. Especially the ending has therefore been necessarily altered. During our field trip to Parc Astérix we were 
rather relieved to find out that 'Le Vol d'Icare' does not drown riders in the artificial lake right opposite the coaster.

\section{Conclusion}

The two rides examined here constitute different medial and cultural translations of ancient Greek myths. Yet while 'El Laberinto' creates a new myth by combining different characters and stories and reinterpreting them according to modern cultural sensibilities, 'Le Vol d'Icare' stays fairly close to the traditional plot, although here too modern elements are introduced to the story. Both attractions rely nonetheless on a quite limited and easily recognizable set of iconographies and visual references to translate myth, as theorized by the strategies of selection and abstraction in our model of translation. Perhaps, most importantly, both attractions rely on the palace of Cnossos to establish the geography and the time of the myth referred to. This is not surprising, however, as the translation of myth is based on recognition: the smaller the repertoire, the higher the chances of recognition by the visitor.

To be sure, 'El Laberinto' works with a much wider selection of iconographies, one that also includes films and video games. This, however, is related to the genre of the ride and the number of myths translated by it. In 'Le Vol d'Icare', the 'fidelity' to a myth that has known a scarce representation in, for example, films, as well as the decision to represent the labyrinth as a ruin, without living beings, has limited the amount of such intermedial references.

A smaller number of references does not in any case endanger the possibility of recognition, as is made clear by another attraction, again from Terra Mítica, that refers to the myth of Icarus. 'Los Icaros', a simple chain-swing ride, features nothing but drawings of Greeklooking people with wings and offers nothing but the possibility of seeing, from the swings, the 
Mediterranean Sea. In the context of a park like Terra Mítica, however, the reference is clear enough to enable recognition and make this too a way of translating myth.

\section{References}

Alvaro, Corrado (1949), La lunga notte di Medea/The Long Night of Medea, stage play.

Anon. (1910), The Minotaur, USA: Vitagraph Company of America.

Berti, Irene and Carlà, Filippo (2015), 'Magic and the supernatural from the ancient world: An introduction', in Irene Berti and Filippo Carlà (eds), Ancient Magic and the Supernatural in the Modern Visual and Performing Arts, London, etc.: Bloomsbury, pp. 1-17.

Bertolini, Francesco (1911), L'Odissea/The Odyssey, Italy: Milano Film.

Bieger, Laura (2007), Ästhetik der Immersion: Raum-Erleben zwischen Welt und Bild. Las Vegas, Washington und die White City/'The aesthetics of immersion: experiencing spaces between world and image. Las Vegas, Washington, and the White City', Bielefeld: Transcript.

BlueSky (1991), Arachnophobia, video game, Burbank: Walt Disney Company. 
Carlà, Filippo (2008), 'Pasolini, Aristotle and Freud: Filmed drama between psychoanalysis and "Neoclassicism", in Irene Berti and Marta García Morcillo (eds), Hellas on Screen: Cinematic Receptions of Ancient History, Literature and Myth, Stuttgart: Franz Steiner, pp. 89-115.

(2015a), 'Historische Quellen, literarische Erzählungen, phantasievolle Konstruktionen: Die vielen Leben der Theodora von Byzanz'/'Historical sources, literary narrations, imaginative constructions: the many lives of Theodora of Byzantium', in Jutta Ernst and Florian Freitag (eds), Transkulturelle Dynamiken: Aktanten - Prozesse - Theorien/`Transcultural dynamics: actors - processes - theories', Bielefeld: Transcript, pp. 31-62.

(2015b), ‘Atena e l'ottovolante: “affective turn”, estetica postmoderna e ricezione dell'antico'/Athena and the Roller Coaster: "affective turn", postmodern aesthetics and the reception of Antiquity', Status Quaestionis, 8, http://ojs.uniroma1.it/index.php/statusquaestionis. Accessed 6 October 2015.

Carlà, Filippo and Freitag, Florian (2015a), 'Ancient Greek culture and myth in the Terra Mítica theme park', Classical Receptions Journal, 7:2, pp. 242-259.

(2015b), 'Strategien der Geschichtstransformationen in Themenparks'/'Strategies of transforming history in theme parks', in S. Georgi et al. (eds), Geschichtstransformationen: Verfahren, Medien und Funktionalisierungen historischer Rezeption/‘Transformations of history: the strategies, media, and functions of historical reception', Bielefeld: Transcript, pp. 131-49. 
(2016), 'Cruising Mare Nostrum: The ancient Mediterranean and ancient mythological sea travellers in theme park attractions', in A. Freire Nogueira and R. Rovira Guardiola (eds), Sailing in Troubled Waters: The Ancient Mediterranean in the Visual and Performing Arts, London, etc.: Bloomsbury.

Carruesco, Jesús and Reig, Montserrat (2015), 'Medea, a Greek sorceress in modern opera and ballett: From Barber to Reimann', in Irene Berti and Filippo Carlà (eds), Ancient Magic and the Supernatural in the Modern Visual and Performing Arts, London, etc.: Bloomsbury, pp. 93-102.

Castello, Maria G. and Scilabra, Carla (2015), 'Theoi becoming Kami: Classical mythology in the anime world', in Irene Berti and Filippo Carlà (eds), Ancient Magic and the Supernatural in the Modern Visual and Performing Arts, London, etc.: Bloomsbury, pp. 177-96.

Castleden, Rodney (1989), The Knossos Labyrinth: A New View of the 'Palace of Minos' at Knossos, London and New York: Routledge.

Clavé, Salvador Anton (2007), The Global Theme Park Industry, Cambridge: CABI.

Davis, Desmond (1981), Clash of the Titans, USA: Metro-Goldwyn-Mayer.

Dürrenmatt, Friedrich (1985), Minotaurus: Eine Ballade/Minotaur: A Ballad, Zürich: Diogenes.

The Flintstones (1960-1966, USA: ABC). 
Goscinny, René and Uderzo, Albert (1968), Astérix aux Jeux Olympiques/Asterix at the Olympic

Games, Neuilly-sur-Seine: Dargaud. (1976), Les douze travaux d'Astérix/The Twelve Tasks of Asterix, France: Studio Idéfix and Les Films Daguard.

Hamilton, Guy (1974), 007 - The Man with the Golden Gun, UK: Eon Productions and Danjaq.

Hitchcock, L. and Koudounaris, P. (2002), 'Virtual discourse: Arthur Evans and the reconstructions of the Minoan Palace at Knossos', in Y. Hamilakis (ed.), Labyrinth Revisited: Rethinking 'Minoan'Archaeology, Oxford: Oxbow Books, pp. 40-58.

Hubbard, Thomas K. (1987), 'Two notes on the myth of Aeacus in Pindar', Greek, Roman, and Byzantine Studies, 28:1, pp. 5-22.

Hughes-Warrington, Marnie (2007), History Goes to the Movies: Studying History on Film, London, etc.: Routledge.

Keaton, Buster (1923), Three Ages, USA: Buster Keaton Productions.

Kinder, Marsha (1991), Playing with Power in Movies, Television, and Video Games, Berkeley: University of California Press. 
Lane Fox, Robin (2008), Travelling Heroes: Greeks and Their Myths in the Epic Age of Homer, London: Allen Lane.

Lukas, Scott A. (2007), 'A politics of reverence and irreverence: Social discourse on theming controversies', in Scott A. Lukas (ed.), The Themed Space: Locating Culture, Nation, and Self, Lanham, MA: Lexington, pp. 271-93.

Luske, Hamilton and Sharpsteen, Ben (1940), Pinocchio, USA: Walt Disney Company.

MacGillivray, J. A. (2002), 'Memories of a Minotaur', in J. Driessen, I. Schoep and R. Laffineur (eds), Monuments of Minos: Rethinking the Minoan Palaces, Liège: Peeters, pp. 213-16.

Marshall, Frank (1990), Arachnophobia, USA: Hollywood Pictures and Ambline Enterainment.

Melotti, Marxiano (2008), Turismo archeologico: Dalle piramidi alle veneri di plastica/'Archaeological tourism: from the pyramids to the plastic Venuses', Milano: Bruno Mondadori.

Pasolini, Pier Paolo (1969), Medea, Rom, Paris and Frankfurt am Main: San Marco, Films Number One S.a.r.l., Janus Film and Fernseh-Produktion GmbH.

Pastrone, Giovanni (1911), La caduta di Troia/The Fall of Troy, Italy: Itala Film. 
Preußer, Heinz-Peter (2013), 'Mythos als Meta- und Konnotationsnarrativ: Antikenrezeption und Popkultur im Kino seit dem Jahr 2000'/'Myth as meta-narrative and narrative of connotation: classical reception and popular culture in cinema since 2000', in Brigitte Krüger and HansChristian Stillmark (eds), Mythos und Kulturtransfer: Neue Figurationen in Literatur, Kunst und modernen Medien/'Myth and cultural transfer: new figurations in literature, art, and modern media', Bielefeld: Transcript, pp. 61-106.

Pucci, Giuseppe (2013), 'Dall'hic et nunc all'ubique et semper?'/‘From the hic et nunc to the ubique et semper?', Rivista di estetica, 52:1, pp. 181-91.

Reimann, Aribert (2007/2009), Medea, opera.

Rouse, W. H. D. (1901), 'The double axe and the labyrinth', Journal of Hellenic Studies, 21, pp. $268-74$.

Scott, Jill (2004), 'Translating myth: The task of speaking time and space', in K. M. Faull (ed.), Translation and Culture, Lewisburg, PA: Bucknell University Press, pp. 58-72.

Shanower, Eric (1998-), Age of Bronze, Berkeley, CA: Image Comics. 
(2011), 'Twenty-first century troy, or, how do you solve a problem like Iphigenia and other

matters of grave import', in George Kovacs and C. W. Marshall (eds), Classics and Comics, Oxford: Oxford University Press, pp. 195-206.

Solomon, Jon (2001), The Ancient World in the Cinema, New Haven: Yale University Press.

Spielberg, Steven (1981-2008), Indiana Jones series, USA: Paramount Pictures and Lucasfilm.

Verreth, Herbert (2008), 'Odysseus' journey through film', in Irene Berti and Marta García Morcillo (eds), Hellas on Screen: Cinematic Receptions of Ancient History, Literature and Myth, Stuttgart: Franz Steiner, pp. 65-73.

Welles, Orson (1947), The Lady from Shanghai, USA: Columbia Pictures Corporation and Mercury Productions.

Winter, Sarah (1997-1998), “'Schoolboy Psychology”: Freud's classical education and the institutionalization of psychoanalytic knowledge', Cultural Critique, 38, pp. 137-75.

Wyke, Maria (2013), 'Silent laughter and the counter-historical: Buster Keaton's Three Ages (1923)', in Pantelis Michelakis and Maria Wyke (eds), The Ancient World in Silent Cinema, Cambridge: Cambridge University Press, pp. 275-96. 
Zajko, Vanda and O'Gorman, Ellen (2013), 'Introduction: Myths and their receptions: Narrative, antiquity and the unconscious', in Vanda Zajko and Ellen O' Gorman (eds), Classical Myth and Psychoanalysis: Ancient and Modern Stories of the Self, Oxford: Oxford University Press, pp. 117.

\section{Contributor details}

Filippo Carlà is lecturer in Classics and Ancient History at the University of Exeter. He studied Classics and Ancient History at the Universities of Turin and Udine, and taught and researched at the Universities of Heidelberg and Mainz. His main research interests are the cultural history of the Ancient world, the social and economic history of Ancient Rome and the reception of classical Antiquity in modern popular culture, in particular in the visual and performing arts. Together with Florian Freitag, he leads the research project 'Here You Leave Today: Time and Temporality in Theme Parks', in which he in particular investigates representations of classical Greece in theme parks all over the world.

Florian Freitag received his Ph.D. in American Studies from the University of Konstanz (Germany) in 2011. Since then he has been lecturer in American Studies at Johannes Gutenberg University Mainz (Germany). His research interests include regionalism, Periodical studies, and Theme Park studies. Freitag is the author of The Farm Novel in North America (2013); his other work has appeared in Amerikastudien/American Studies, Zeitschrift für Kanada-Studien, Canadian Literature, The Journal of Popular Culture and the Palgrave Handbook of Comparative North American Literature. Freitag's current projects include an edited collection about time and temporality in theme parks and a monograph on the representation of New Orleans in popular culture. Together with Filippo Carlà, he leads an interdisciplinary research group on theme parks, funded by the German Research Foundation (DFG). 
Contact:

Filippo Carlà, Department of Classics and Ancient History, Amory Building, University of Exeter, Rennes Drive, Exeter EX4 4RJ, United Kingdom.

E-mail: F.F.Carla@exeter.ac.uk

Florian Freitag, Johannes Gutenberg University Mainz, An der Hochschule 2, 76726

Germersheim, Germany.

E-mail: freitagf@uni-mainz.de

Notes

1 'The aura that one can perceive in front of the throne of Minosses is an artificially induced aura, an aura which is based not on the authenticity of the monument itself, but on the locality one could say the location - in which the reconstruction is proposed as well as on its evocative power, on the capacity of the site in its complex to recall the encyclopaedia of the observer' (trans. F. Carlà).

${ }^{2}$ A very good example of the hardships connected to any attempt to weave together and reconcile all the different (and contradictory) traditions (ancient and modern!) about the Trojan War is provided by Shanower 2011.

${ }^{3}$ This chapter is based on Carlà and Freitag (2015b), in which we describe our model in detail.

${ }^{4}$ E.g. http://www.telegraph.co.uk/news/worldnews/europe/greece/6343458/Crete-quarry-couldbe-original-site-of-ancient-Greek-Labyrinth.html, accessed 13 April 2015. Nicholas Howarth, the geographer who supported this theory and presented it to the press in 2009 , does not seem to have ever published it. 
${ }^{5}$ It might be worth noting that already Homer places Daedalus' building activity at Cnossos; he does not refer to the construction of a labyrinth, though, but of a dancing floor built for Ariadne: Il. $18.590-592$.

${ }^{6}$ Castleden, a volume that has been reviewed very negatively, refers throughout the book to the palace as 'the Knossos Labyrinth' (1989). 